\title{
The CHINA CONNECTION: Michael Rossmann and his first encounter with me
}

\author{
Jia-huai Wang ( $₫)$ \\ Dana-Farber Cancer Institute, Harvard Medical School, Boston MA 02115, USA \\ $\bowtie$ Correspondence: jwang@red.dfci.harvard.edu
}

"We would have never belived it, if it were not told by Dorothy Hodgkin," Michael Rossmann of Purdue University said to me. He was referring to what the late Nobel laureate Dorothy Hodgkin announced in an international meeting about the achievements of Chinese scientists in determining the crystal structure of insulin in early 70's. This significant contribution occurred at the time when China was still deeply entangled in the chaos of the Cultural Revolution, while even in the international community there were less than a dozen protein structures solved by scientists (Michael included) from a handful of countries. Michael and I sat in his cozy dinning room. While enjoying a breakfast with his favorite applesauce, observing a wild rabbit sneaking underneath the bush in the garden, we had a long chat. That was during my first visit to his lab in West Lafayette in 1980.

I first came to the United States in the autumn of 1979, when China had just begun to open its doors. The Chinese Academy of Sciences (CAS) immediately decided to send visiting scholars abroad. I was working in the Institute of Biophysics, CAS, and was among the early group of people preparing to go to the United States. Since Chinese scientists had no contacts with the outside world for more than a decade, no one even knew how to re-establish a connection with foreign scientists. My thought was simple. From the insulin project, I knew at least a little about protein structure, so ideally I would like to learn something about the nucleic acid. To my knowledge, in the U.S. there are Michael at Purdue and Steve Harrison at Harvard-the two pioneers in the field of structural virology-working on the RNA virus. Alexander Rich of MIT was also working on the structure of tRNA. Given the delicate political situation at the time, I was not sure whether it was appropriate to communicate directly with the Western world. I decided to write my application to CAS. Half a year passed, no one replied. Then the opportunity arrived, when the President of University of Wisconsin led a large delegation to China. He expressed his enthusiasm to welcome Chinese visiting scholars to his University for pursuing career advancement. In his faculty roster, I discovered that Professor *Sundaralingam's lab was also working on the tRNA structure. Sponsored by the Chinese government, I arrived at Madison-a beautiful midwestern town. Soon after, Sunda, as people normally called him, felt pretty upset by seeing me working hard at his lab without paying me a penny. One day he informed me that he decided to give me some stipend. I told him that any money he pays me would have to be handed back to the CAS, which would result in a situation of the NIH paying the CAS. That won't work. Eventually we reached a nice arrangement: To use his fund for my extensive academic travel to other major structural biology labs in the U.S. Thirty years ago, even in the U.S., there were not many first class structural biology labs. I was keen to see their efforts in advancing this important field in modern biology. Michael's lab was the first one I picked for a visit.

During my two-day visit, Michael and I had several long chats, in his office, at his house, while dining in a local Chinese restaurant, and strolling in the wood (strolling is one of Michael's favorite hobbies). He described to me his early years at Cambridge, U.K. He even made a napkin sketch of the lab setting of the prestigious Cavendish laboratory, the birthplace of protein crystallography. I elaborated to him the absolutely isolated working conditions of the young Chinese group that did the insulin structure. Having heard all these amazing stories, Michael eagerly expressed his desire of

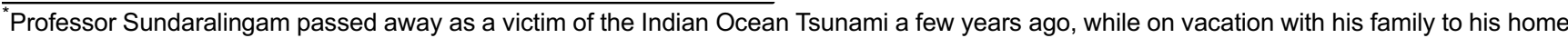
country, Sri Lanka.
} 
paying a Beijing visit. He really wanted to see the lab through his own eyes. One night, after a visit to his wife Audrey's pottery workshop in the basement, we sat down for a cup of tea. He suddenly lit up with an exciting idea. "Can you make a phone call to your lab in Beijing to arrange a visit for me?" Michael asked. What seems matter-of-fact now was a big question mark for that era. Remember, this was at a time when the Sino-US relationship had only a couple of year history. In the U.S. in 1980, there were probably no more than a few hundred Chinese scholars and students from Mainland China. I frankly was clueless as to how, who, or if it was possible to make such a call at all. I looked into Michael's sincere and anxious face, and could not refuse to give it a try. Michael quickly seized my instant consent. He pointed to the telephone set at the coffee table, and said resolutely: "Just try this one, now, Jia-huai!"

It was an unforgettable experience, when I put my ear against the receiver and heard the ringtone from the other side of the world! Until the 1990's, the Institute of Biophysics never had her own building. The main part of the Beijing Insulin lab was located on the first floor in the old Microbiology Building in CAS's Zhongguancun campus. There was only one communal telephone set in the entire corridor. One of my colleagues answered the phone. I began to shout: "I am Jiahuai calling from USA. Is Lao Liang there?" I was referring to Dr. Dongcai Liang, the head of the Insulin group. Dongcai happened to have stepped out. Another senior lab member took over the phone. I explained to him where and why I was making the call. In particular, I told him that Michael was very eager to pay a visit. He replied without hesitation: "Michael would certainly be very warmly welcomed!" Jia-huai called from America! News rippled through like a front-page headline. My wife was a college chemistry teacher. She liked to prepare her lectures in the Biophysics Institute's library, a much quieter and more spacious space than my nearby tiny apartment. Learning the news, she dashed into sight and seized the opportunity. She chatted on with updates about our trouble-making son and the lovely little daughter. Standing by and watching me on the phone for so long, Michael started to get a bit upset. He pointed to the phone set: "Jia-huai, this must be terribly expensive..." I had to quickly stop my wife. Frankly, I have never told Michael who actually extended the phone call longer than it should have been.

Michael was so excited to learn that things went so smoothly through a simple private phone call. By next morning he could hardly contain himself: "I am going to visit China!" It probably sounded like just a slightly smaller feat than the Apollo trip. As the initial exhilaration subsided, he soon realized he's faced with a very practical issue. In the China of 1980, there are hardly any English-speaking Chinese to be found. Michael, of course, knew zero about Chinese. He asked me what if he gets lost from the airport to the Institute? This was a real problem indeed. I felt a serious responsibility. Then an idea popped into my head. I asked Michael to hand me a large piece of paper. On one side, I wrote in English:"I am Professor Michael Rossmann from Purdue University of the United States. I come to visit Institute of Biophysics." On the other side, it was a Chinese translation. I told Michael to hold the paper high whenever necessary.

It turned out to be a real adventure! Michael recounted the story to me one year later when we met again at a meeting in a small village in Sicily (Fig. 1). His airplane arrived at Beijing ahead of schedule. Dongcai was still on his way to the airport. Michael passed through custom only to find no one from the Institute to greet him. He became very nervous, and decided to look for a taxi. There were probably only a few hundred taxis altogether in the entire city of Beijing at the beginning of 80 's. Michael managed to find one. Needless to say, the driver did not speak any English. Michael showed the driver the paper's Chinese side. Fortunately the taxi driver knew where to go. When Michael got off the taxi, a huge crowd immediately gathered around him. After all, even at CAS, foreign visitors were a rare sight at that time. Michael started to get nervous again. He did not know what to do except for holding up the paper, and murmured: "I am Michael Rossmann. I am here to visit the Institute of Biophysics". "He is our guest. We have been expecting him!" One of my friends in the Insulin group shouted in Chinese. The rest of Michael's visit was unbelievably pleasant. Michael immensely enjoyed discussing science, making friends and seeing the beautiful Beijing. Since then several lab members in the Insulin group arranged to go to Michael's lab as visiting scholars. Michael was invited to serve as a consultant to the lab. Michael later started to successfully train many graduate students from China. More than two decades later, I went to West Lafayette again for Michael's 75th-year birthday celebration. It was a great pleasure to meet many of his former Chinese students, who had become well established in their own right!

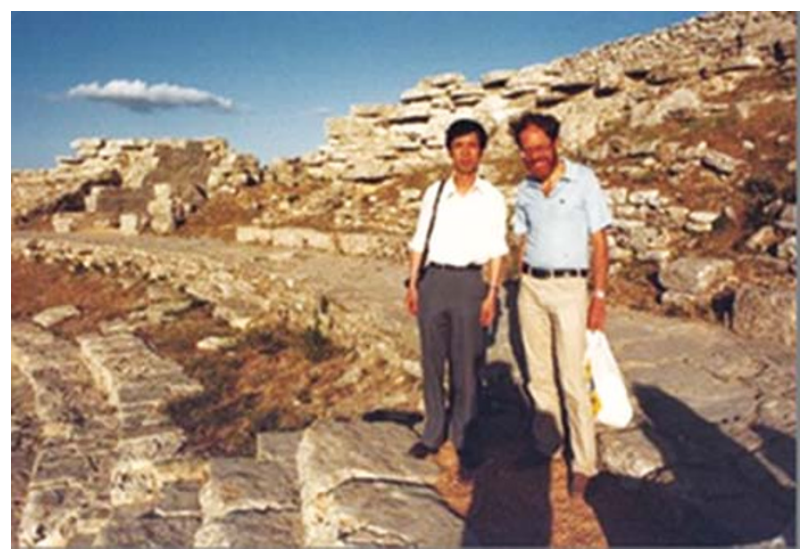

Figure 1. Jia-huai Wang and Michael Rossmann in Sicily

"Jia-huai, why you did not choose to join my lab in the first place?" Michael stared at me with a puzzling expression at the dinner table during my 1980 -visit. "That was probably your 
fault." I began to tease Michael. "I sent you an application, but you never replied." "What, did you?" Michael said he never received any applications from me. Steve Harrison and Alex Rich later gave me the same answer. Apparently, I sent my application letters to the wrong places. Since I had already got an offer from Steve to join an extremely exciting project in 1981 to carry out structural studies on how a repressor protein specifically recognizes a small piece of DNA, the operator site. In retrospect, I always felt so regret to miss the opportunity to work with Michael.

I actually ended up competing with Michael 20 years later on the structure of ICAM-1 (intercellular adhesion molecule1). Michael became interested in this protein largely because ICAM-1 is the receptor of the major group of rhinovirus, a virus that causes the common cold. Michael solved the structure of rhinovirus. He was eager to understand how the virus interacts with the receptor. My major focus at Dana-Farber has been the structural investigation into cell adhesion molecules. One of my major collaborators within our medical campus, Dr. Timothy Springer had first characterized ICAM-1.
ICAM-1 plays an important role in leukocyte recruitment from blood stream to the site of infection or injury, and in the formation of immunological synapses for $\mathrm{T}$ cell activations. We wanted to see the structure of ICAM-1 more from the immunological perspective. Coincidentally, the postdoctoral fellows who worked on the structure on both sides also happened to be friends from Spain! Eventually we both solved the structure about the same time and agreed to publish in $P N A S$ back-to-back in the same issue.

Since 1980, I have visited Michael quite a few times, including one visit at Michael's invitation to give a talk on the structure of ICAM-1. When Michael introduced me to the audience, he said: "Jia-huai is my first Chinese friend." Apparently many of his lab members, particularly those Chinese students and postdoctors already knew the story about my first visit. Michael continued: "Friends may also compete, like what Jia-huai and I did. But we did it in a very gentleman style!" I was pretty touched. After all, we are serious scientists. "We all love science", as Michael once emphasized to me.

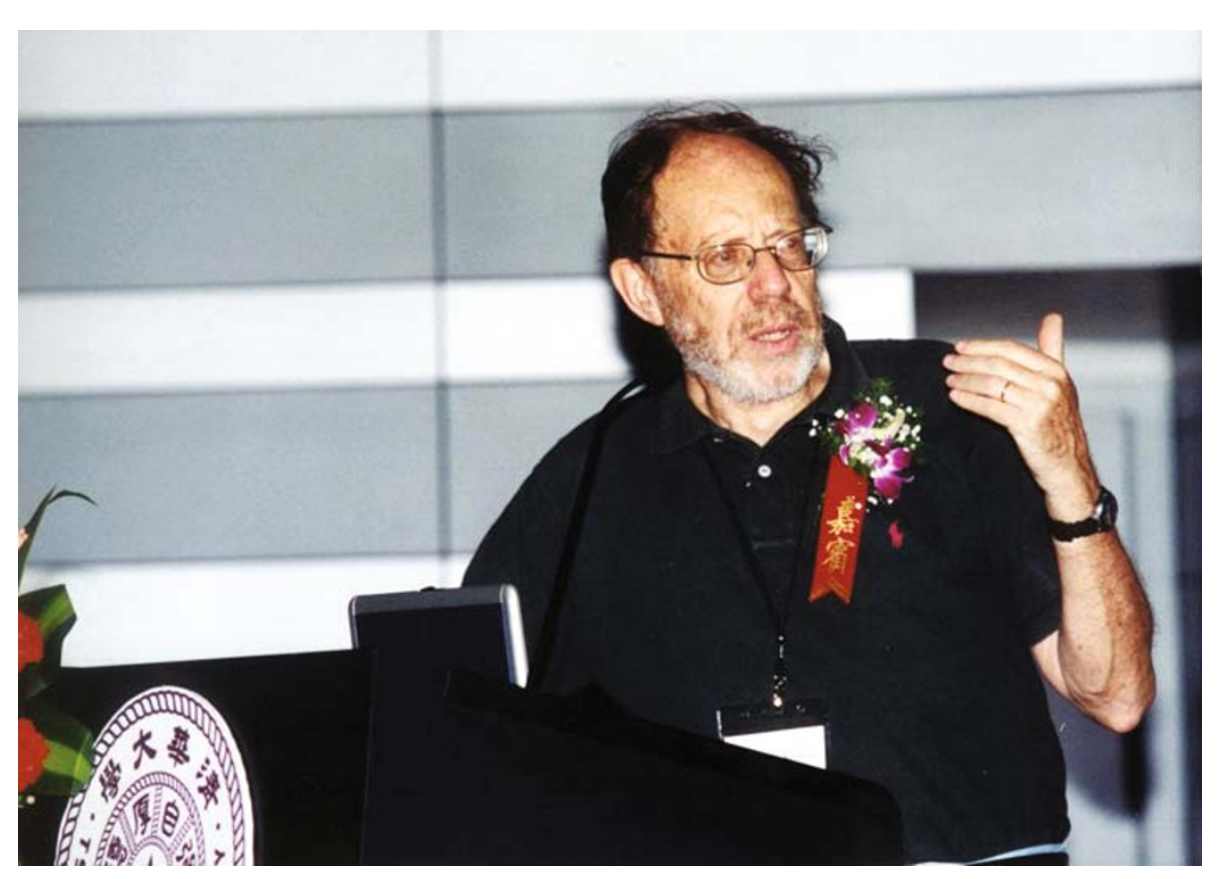

Figure 2. Michael Rossmann on the 10th International Conference on the Crystallization of Biological Macromolecules (ICCBM) in Beijing (2004) 